\title{
Potassium Fertilization and Physiological Soybean Seed Quality
}

\author{
Everton Vinicius Zambiazzi, Adriano Teodoro Bruzi*, Maria Laene Moreira de Carvalho, \\ Igor Oliveri Soares, Alan Mario Zuffo, Pedro Milanez de Rezende, Diego Henrique Miranda \\ Department of Agriculture, Federal University of Lavras (UFLA), Lavras, Brazil \\ Email: ${ }^{*}$ adrianobruzi@dag.ufla.br
}

Received 11 July 2014; revised 18 August 2014; accepted 17 September 2014

Copyright (C) 2014 by authors and Scientific Research Publishing Inc.

This work is licensed under the Creative Commons Attribution International License (CC BY). http://creativecommons.org/licenses/by/4.0/

(c) (i) Open Access

\section{Abstract}

The purpose of this study was to evaluate the influence of increased application rates of potassium on the physiological quality of seeds from different soybean cultivars. Seeds from two locations (São Gotardo, MG and Lavras, MG, Brazil) were used. After harvest, the seeds were sent to the Central Seed Analysis Laboratory of the Federal University of Lavras. We used a randomized design in a $4 \times 6$ factorial arrangement of four cultivars and six doses of potassium. All tests were performed with two replicates of 50 seeds ( 300 seeds per treatment). Germination, emergence under controlled conditions, accelerated aging, electrical conductivity, and tetrazolium tests were performed. Data were subjected to analysis of variance. In soybean seed production fields with high potassium content in the soil, higher application rates of potassium do not increase the physiological quality of seeds.

\section{Keywords}

Glycine max L., Seed Vigor, Seed Production

\section{Introduction}

The use of high vigor seeds in soybean is critical in establishing the crop and bringing about high yield. In this context, it should be noted that nutrient availability can influence the chemical composition of seeds and therefore their metabolism. Thus, an adequate supply of nutrients can provide for good plant development and produce metabolites for seed development.

The chemical composition of seeds may be influenced by genetic factors, the environment, and, moreover, the nutrients applied to the soil. Potassium fertilization can influence germination and seed vigor since it is an es-

${ }^{*}$ Corresponding author.

How to cite this paper: Zambiazzi, E.V., Bruzi, A.T., de Carvalho, M.L.M., Soares, I.O., Zuffo, A.M., de Rezende, P.M. and Miranda, D.H. (2014) Potassium Fertilization and Physiological Soybean Seed Quality. Agricultural Sciences, 5, 984-991. 
sential element for oil synthesis and transport in soybeans [1] [2]. Similar results were obtained by [3], who found that seed vigor was significantly affected by potassium fertilization rates.

Some authors show the evident importance of maintaining high potassium concentration in plant tissue and grain; and a higher potassium level in grain is positively associated with yield and physiological quality [4]. In a study by [5], the author states that the rates of pathogens in seeds increase when less than $120 \mathrm{~kg} \cdot \mathrm{ha}^{-1}$ is applied, indicating that potassium deficiency may predispose seeds to infection by numerous pathogens.

In general, the literature reports that seed quality is significantly higher when potassium is applied at rates greater than $80 \mathrm{~kg} \cdot \mathrm{ha}^{-1}$ [5]. However, results are still contradictory [6]. Thus, the aim of this study was to evaluate the influence of potassium application rates on the physiological quality of seeds from different soybean cultivars.

\section{Materials and Methods}

The study was performed at the Central Seed Analysis Laboratory of the Universidade Federal de Lavras (Federal University of Lavras) —UFLA (Lavras, Minas Gerais [MG], Brazil). We used seeds from Lavras and São Gotardo, MG. Chemical and physical analyses of the field experiments, and rainfall and average temperature results of the sites are shown in Table 1 and Figure 1.

A randomized complete block design with three replications was used in a $4 \times 6$ factorial arrangement, with four soybean cultivars (TMG 127 RR, TMG 1179 RR, BRS MG 850 GRR, and NA 7255 RR) and six potassium application rates $\left(0,40,80,120,160\right.$, and $\left.200 \mathrm{~kg} \cdot \mathrm{ha}^{-1}\right)$. Potassium chloride $\left(\mathrm{KCl}^{-}\right)$with $60 \% \mathrm{~K}^{+}$was used as a source. Each plot consisted of two $5 \mathrm{~m}$ rows at a spacing of $0.5 \mathrm{~m}$.

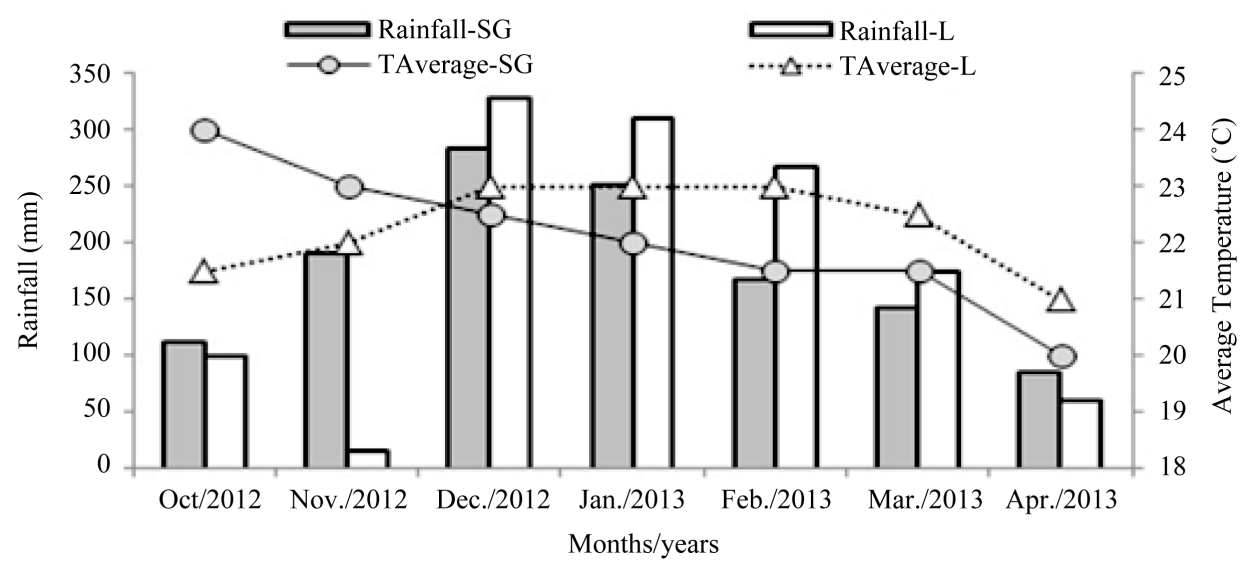

Figure 1. Monthly rainfall and air temperature average in São Gotardo, MG (SG) and Lavras, MG (L) over the 2012/2013 crop season. Source: National Institute of Meteorology (INMET).

Table 1. Chemical and physical composition of a Distroferric typical Oxisol soil $(0-20 \mathrm{~cm})$ before setting up the experiments in Lavras, MG and São Gotardo, MG in the 2012/2013 crop season.

\begin{tabular}{|c|c|c|c|c|c|c|c|c|c|c|c|}
\hline \multirow{2}{*}{ Site } & $\mathrm{pH}$ & $\mathrm{Ca}^{2+}$ & $\mathrm{Mg}^{2+}$ & $\mathrm{Al}^{3+}$ & $\mathrm{H}^{+}+\mathrm{Al}^{3+}$ & SB & CEC & $P$ & K & OM & $\mathrm{V}$ \\
\hline & $\mathrm{H}_{2} \mathrm{O}$ & \multicolumn{6}{|c|}{$\mathrm{cmol}_{\mathrm{c}} \cdot \mathrm{dm}^{-3}$} & \multicolumn{2}{|c|}{$\mathrm{mg} \cdot \mathrm{dm}^{-3}$} & dag $/ \mathrm{kg}^{-1}$ & $\%$ \\
\hline São Gotardo ${ }^{1}$ & 5.27 & 3.60 & 1.10 & 0.08 & 7.05 & 4.90 & 11.90 & 28.14 & 103 & 4.68 & 40.94 \\
\hline Lavras $^{2}$ & 5.90 & 4.70 & 1.30 & 0.00 & 2.90 & 6.30 & 9.20 & 7.21 & 118 & 2.61 & 68.51 \\
\hline \multirow{2}{*}{ Site } & $\mathrm{Zn}^{2+}$ & $\mathrm{Mn}^{2+}$ & $\mathrm{Cu}^{2+}$ & B & $\mathrm{Fe}^{2+}$ & $S$ & Clay & Silt & Sand & Text & lass \\
\hline & \multicolumn{5}{|c|}{$\mathrm{mg} / \mathrm{dm}^{3}$} & & \multicolumn{3}{|c|}{ dag/kg } & \multicolumn{2}{|c|}{-} \\
\hline São Gotardo ${ }^{1}$ & 17.10 & 14.50 & 11.30 & 0.50 & - & - & 50 & 28 & 22 & \multicolumn{2}{|c|}{ Clayey } \\
\hline Lavras $^{2}$ & 5.31 & 13.33 & 0.60 & 0.33 & - & - & 64 & 20 & 16 & \multicolumn{2}{|c|}{ Clayey } \\
\hline
\end{tabular}

$\mathrm{H}+\mathrm{Al}^{3+}$ : potential acidity; SB: sum of bases; CEC: cation exchange capacity at pH 7.0; OM: organic matter; V: base saturation. ${ }^{1}$ Experimental area of the Experimental Farm of the Cooperativa Agropecuária do Alto Paranaíba Ltda—COOPADAP. ²Experimental area of the Centro de Desenvolvimento Científico e Tecnológico em Agropecuária of the Universidade Federal de Lavras. 
The experiments were harvested manually and then threshed mechanically. Samples from the plots were homogenized and classified by sieving. For the laboratory tests, we used the seeds contained in the 5.5 and $6.0 \mathrm{~mm}$ sieves.

The field experiment laboratory evaluations were performed using a randomized design; all tests were performed with two replicates of 50 seeds per replicate, totaling 300 seeds per treatment. Physiological quality was evaluated by the following tests:

Germination: seeds were distributed on germitest paper towel with a distilled water volume at the ratio of 2.5 times the dry weight of the substrate. They were then placed in a Mangelsdorf model germination chamber at a temperature of $25^{\circ} \mathrm{C}$. Evaluations were performed on the 8th day after sowing, according to the criteria set forth in the Regra de Análises de Sementes (Seed Analysis Guidelines) [7]. The mean results were expressed as a percentage of normal seedlings.

Accelerated Aging: in this test we adopted the criteria established by [8]. We used $42 \mathrm{~g}$ of seed samples per treatment. The samples were placed on stainless steel screens adapted to plastic gerbox boxes with $40 \mathrm{~mL}$ of water at the bottom. The boxes were sealed and taken to a water-jacketed model incubation chamber set at $41^{\circ} \mathrm{C}$ for $72 \mathrm{~h}$. Then the seeds were subjected to germination tests and the evaluations as described in the methodology above.

Emergence under controlled conditions: the substrate was composed by mixing soil + sand $(2: 1)$ and then placed in plastic trays. Upon sowing, the seeds were covered with a layer of substrate $(2-3 \mathrm{~cm})$. The trays were kept in a plant growth chamber at $25^{\circ} \mathrm{C}$ with daily watering according to plant needs. As of emergence of the first seedling (cotyledon visible), daily evaluations were performed by computing the number of seedlings until stabilization, with final evaluations at 14 days after sowing. The average percentage at the end of emergence (\% E) was considered. To calculate the speed of emergence index (ESI) of the seeds, we adopted the equation suggested by [9].

Tetrazolium test: the seeds were placed on moistened germitest paper and kept for 16 hours at $25^{\circ} \mathrm{C}$. After this period, the seeds were placed fully submerged in $0.075 \%$ tetrazolium salt solution in plastic containers, remaining for three hours at $40^{\circ} \mathrm{C}$ in a water-jacketed model incubation chamber. After this period, the seeds were washed in water and again placed in plastic containers with water. Then viability and vigor were determined by classifying each seed in one of the eight groups described by [10].

Electrical conductivity: we used the conductivity of mass method and placed 50 previously weighed seeds/ replicates in plastic beakers containing $75 \mathrm{~mL}$ of deionized water and then transferred them to an incubator chamber regulated at the temperature of $25^{\circ} \mathrm{C}$ for 24 hours [11]. After this period, the containers were removed from the incubator chamber and gently stirred, and the electrical conductivity of the solution was measured with the aid of a conductivity meter (MS TECNOPON ${ }^{\circledR}$-mCA150). The mean values were expressed as $\mu \mathrm{S} \cdot \mathrm{cm}^{-1} \cdot \mathrm{g}^{-1}$.

After collecting and tabulating the data, all the evaluated parameters were analyzed. Mean values were compared according to [12] at 5\% probability. Statistical analysis was performed with the aid of the statistical package [13].

\section{Results and Discussion}

From combined analysis, a significant difference was detected in all the parameters evaluated for cultivars. This was expected since the cultivars have different growth habits and genetic backgrounds, leading to such variation. Several reports in the literature show that genotype influences the physiological quality of soybean seeds [6].

There was a significant effect of the production site on the quality of seed lots. The effect of environment on the expression of physiological quality is often highlighted in the literature [6] [14] and this supports the reports obtained in this study. We also found a significant interaction between cultivars and locations, i.e., the cultivars showed no consistent performance irrespective of environment. These results confirm the reports presented by [15]-[17] for physiological quality in different environments. Significant interactions between cultivars and locations have been frequently reported in the literature for physiological seed quality [6] [16] [18]. In fact, this occurred because the two sites were different in altitude and latitude which are essential factors for seed production.

Additionally, we should also highlight the unpredictable environmental factors, such as precipitation and temperature (Figure 1). Considering the period of the field test, it is evident that in December, January, and 
February (Lavras) we have a greater accumulation of rainfall and higher average temperature. This fact may be related to the lower vigor and germination percentage observed in this location compared to São Gotardo.

The main objective of this study concerns the influence of potassium levels on seed quality. However, no significant difference was found for the application rates in the tests carried out. This allows us to infer that the physiological quality of soybean seeds, on average, is not dependent on the potassium application rate used.

There are several reports in the literature that confirm this fact. For [2], increasing potassium application rates did not affect germination and vigor. However, according to [19], potassium promoted higher germination percentage and vigor.

One possible explanation for the doses used not having an effect on the physiological quality of seeds is the high content of potassium in the soil. There are several reports in the literature showing that the effect of potassium on physiological quality, yield, and chemical composition is due to the natural content of the nutrient in the experimental area. According to [1], it is necessary to carry out experiments in areas of low natural nutrient content.

The mean values from individual site analyses are shown in Table 2. Clearly, the São Gotardo environment provided high physiological quality. For germination percentage, for example, the São Gotardo environment had 15.5\% greater germination than Lavras. In this study, seeds from São Gotardo surpassed those produced in Lavras by $31.11 \%$ in the tetrazolium/vigor test. This may be related to the climatic conditions observed in Lavras, especially at harvest time. Excess rainfall provides a favorable microclimate for the occurrence of pathogens and also compromises the physiological quality of seeds.

The average of the cultivars and combined analysis involving all the quality tests shown in Table 2 allow us to infer that BRS MG 850 GRR showed better performance for all tests; however, it did not differ from NA 7255 RR for viability determined by tetrazolium. For germination, the best performance was from BRS MG 850 GRR, at about $81.44 \%$. The other cultivars obtained a germination percentage below that required for the marketing of seeds in Brazil, which is $80 \%$ [20].

One of the factors that contributed to low germination was the high percentage of dead and infected seeds observed in the germination test (Figure 2). Germination percentage was inversely proportional to the percentage of dead and infected seeds observed in seed lots with different cultivars. The seeds are susceptible to contamination from numerous pathogens [21]. The pathogens cause contamination of the seeds, which, because of an increase in the degree of deterioration, resulted in decreased germination and seed vigor [22].

Estimates of higher magnitude were obtained for emergence percentage compared to germination percentage obtained in the laboratory. BRS MG 850 GRR had the highest emergence rate (90\%).

The superiority of the emergence test in relation to the germination test was previously observed by [23] and

Table 2. Mean values of individual and combined analysis per site for germination (G-\%), Emergence (E-\%), emergence speed index (ESI), accelerated aging (AA-\%), electrical conductivity (EC), vigor index (VIG), and seed viability (VIA) tetrazolium, for soybean cultivars evaluated, from Lavras-MG and São Gotardo-MG in the 2012/2013 crop.

\begin{tabular}{|c|c|c|c|c|c|c|c|}
\hline Cultivars & G & $\mathrm{E}$ & ESI & AA & EC & VIG & VIA \\
\hline TMG127 RR & $48.92 \mathrm{c}^{1}$ & $73.08 \mathrm{~b}$ & $45.39 \mathrm{~b}$ & $53.92 \mathrm{c}$ & 114.52 a & $76.06 \mathrm{~b}$ & $85.19 \mathrm{~b}$ \\
\hline NA 7255 RR & $56.81 \mathrm{~b}$ & $76.78 \mathrm{~b}$ & $49.11 \mathrm{~b}$ & $54.25 \mathrm{c}$ & $109.11 \mathrm{a}$ & $80.86 \mathrm{~b}$ & $88.11 \mathrm{a}$ \\
\hline BRS MG 850 GRR & $81.44 \mathrm{a}$ & $90.08 \mathrm{a}$ & $59.75 \mathrm{a}$ & $81.67 \mathrm{a}$ & $72.80 \mathrm{~b}$ & $86.22 \mathrm{a}$ & $91.97 \mathrm{a}$ \\
\hline TMG 1179 RR & $62.42 \mathrm{~b}$ & $76.25 \mathrm{~b}$ & $48.06 \mathrm{~b}$ & $60.92 \mathrm{~b}$ & $117.18 \mathrm{a}$ & $66.25 \mathrm{c}$ & $80.06 \mathrm{c}$ \\
\hline Overall mean $\pm \mathrm{SE}$ & $62.40 \pm 2.61$ & $50.58 \pm 2.56$ & $79.05 \pm 1.48$ & $62.69 \pm 3.88$ & $77.35 \pm 6.19$ & $86.33 \pm 3.35$ & $103.40 \pm 2.17$ \\
\hline CV (\%) & 22.00 & 14.00 & 11.00 & 22.00 & 15.00 & 10.00 & 19.00 \\
\hline \multicolumn{8}{|c|}{ São Gotardo, MG } \\
\hline Overall mean & 70.15 a & $92.51 \mathrm{a}$ & $58.28 \mathrm{a}$ & $80.74 \mathrm{a}$ & $74.70 \mathrm{~b}$ & $92.90 \mathrm{a}$ & 95.99 a \\
\hline CV (\%) & 16.00 & 4.00 & 8.00 & 14.00 & 13.00 & 4.00 & 5.00 \\
\hline \multicolumn{8}{|c|}{ Lavras, MG } \\
\hline Overall mean & $54.64 \mathrm{~b}$ & $65.58 \mathrm{~b}$ & $42.87 \mathrm{~b}$ & $44.64 \mathrm{~b}$ & 132.11a & $61.79 \mathrm{~b}$ & $76.68 \mathrm{~b}$ \\
\hline CV (\%) & 29.00 & 18.00 & 20.00 & 26.00 & 20.00 & 25.00 & 15.00 \\
\hline
\end{tabular}

\footnotetext{
${ }^{1 /}$ Values followed by the same letter belong to the same group by the Scott \& Knott (1974) test at 5\% probability. SE—standard error mean.
} 


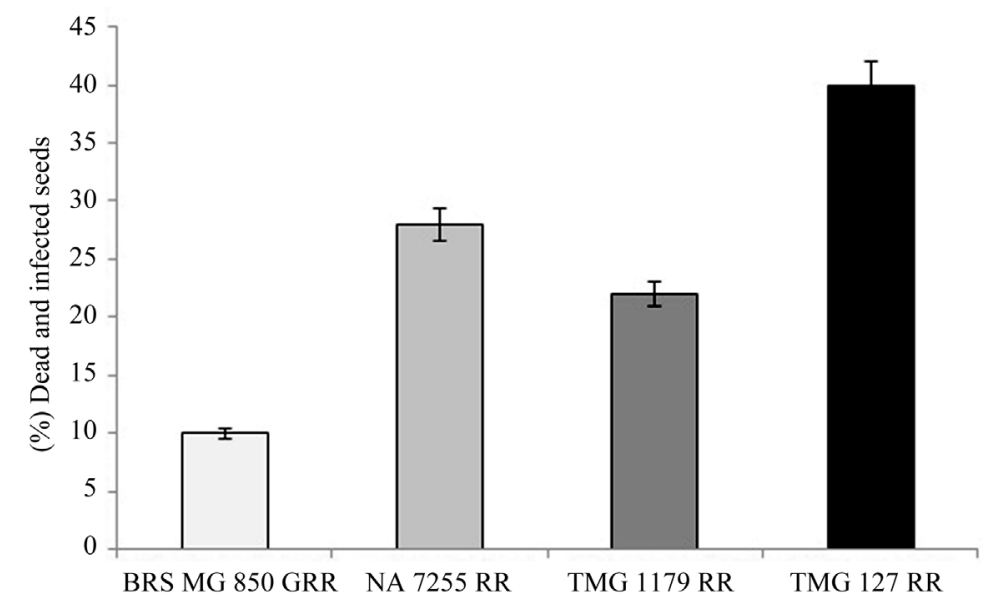

Figure 2. Combined analysis of the total percentage of dead and infected seeds observed in the germination test for each cultivar from Lavras, MG and São Gotardo, MG in the 2012/2013 crop season. Each column represents the mean of three replicates ( \pm standard deviation).

[24]. According to these same authors, this fact can be explained by the escape mechanism in which the seedling releases the infected seed coat to the ground in order to emerge, while in the germination test in the laboratory under roll paper the seed coat remains associated with the cotyledons and the associated fungi cause seed deterioration.

The emergence speed index (ESI) varied among cultivars, with the highest estimate observed for seedlings of the cultivar BRS MG 850 GRR. The speed index is associated with emergence vigor of soybean seeds because seeds with higher ESI tend to perform better and therefore have higher speed of emergence in the field, better resisting the stresses that may occur during emergence [25]. It should also be noted that seeds with higher ESI develop a closed canopy more quickly, which results in efficient weed control [26].

In the accelerated aging test (AA), upon analyzing the mean values of each cultivar, it was observed that the TMG 1179 RR and TMG 127 RR cultivars followed cultivar NA 7255 RR, showing greater sensitivity to conditions of high relative humidity and air temperature.

Accelerated aging is simulation of adverse environmental factors, temperature, and high relative humidity, which are factors seen as causing seed deterioration [8] [27]. Under these conditions, seeds with low physiological quality deteriorate faster than more vigorous seeds, establishing differences in physiological potential [28]. Thus, high vigor seed lots must maintain their viability when subjected to such conditions. Low vigor seeds will bring about reduced viability [29].

In regard to the results for electrical conductivity, the highest values were observed for the cultivars TMG 1179 RR, TMG 127 RR, and NA 7255 RR, differing from BRS MG 850 GRR. According to [30] soybean seed lots with high vigor may have electrical conductivity values of at most $70-80 \mu \mathrm{S} \cdot \mathrm{cm}^{-1} \cdot \mathrm{g}^{-1}$. In this study, the results obtained show that only BRS MG 850 GRR exhibited values considered ideal for electrical conductivity $\left(72.80 \mathrm{mS} \mu \mathrm{S} \cdot \mathrm{cm}^{-1} \cdot \mathrm{g}^{-1}\right)$, thereby leading to production of seeds with high to medium vigor for the cultivar concerned.

For seed vigor and viability, both determined by the tetrazolium test, best performance was observed for BRS MG 850 GRR with $86.22 \%$ and 91.97\%, respectively, although the cultivar NA 7255 RR did not differ in regard to viability.

Among the methods of quality control adopted by seed companies in Brazil, the tetrazolium test stands out for soybean due to the speed, accuracy, and large amount of information provided by the test. In addition, in assessing the viability and vigor of seed lots, it provides possible causes responsible for the reduction in soybean quality that can come from mechanical damage, damage caused by moisture, and damage from stink bug attack, which are the problems that most affect the physiological quality of soybean seeds [10].

It is evident that, on average, the most damage leading to reduction in vigor and viability, assessed by the tetrazolium test, was caused by stink bug attack (48.3\%), moisture content (32\%), and mechanical factors (19.7\%). 


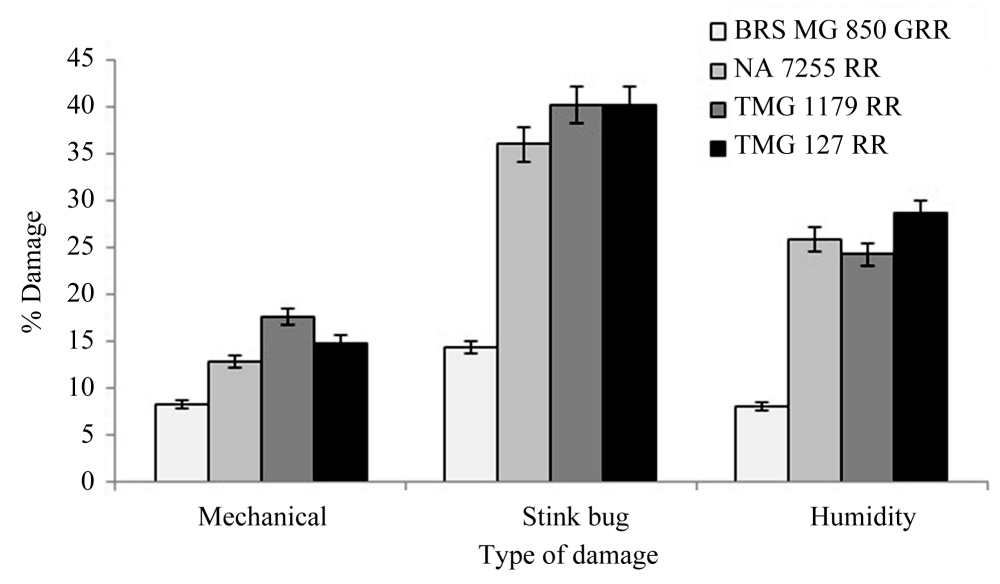

Figure 3. Combined analysis of the damage caused and the respective \% of damage observed in the tetrazolium test for each cultivar from Lavras, MG and São Gotardo, MG in the 2012/2013 crop season. Each column represents the mean of three replicates ( \pm standard deviation).

The main damage observed in the tetrazolium test was that caused by the attack of stink bugs. BRS MG 850 GRR showed $14.3 \%$ damage caused by this insect; the other cultivars showed damage ranging from $35.9 \%$ to $40.2 \%$ (Figure 3).

In the incidence of stink bug, the site of the lesion is more important than the number of bites because damage to the hypocotyl prevents germination, while multiple lesions on cotyledons reduce vigor and emergence, but not germination [31]. Stink bugs can also cause delayed maturation from leaf retention, hampering harvest [32], due to the excessive amount of water present in the plant.

In assessing damage caused by stink bugs in soybean, [33] observed results similar to those found in the present study. They also found correlation between the intensity of the attack of bugs and leaf retention.

The data related to damage caused by moisture show that BRS MG 850 GRR exhibited 8\% damage. The other cultivars exhibited values ranging from $24.3 \%$ to $28.6 \%$, while the cultivar that showed the greatest magnitude was TMG 127 RR. This may be related to the maturity group of each cultivar. BRS MG 850 GRR had samples taken in a period with less rainfall. Thus, the operation was performed when the seeds had lower moisture content, leading to greater vigor and viability compared with other cultivars.

In respect to mechanical damage, 8.2\% injury was noted in BRS MG 850 GRR. The other cultivars showed damage ranging from $12.8 \%$ to $17.5 \%$. Such damage may have been aggravated by mechanical threshing, which favors its occurrence. In a study by [17], evaluating different genotypes in three distinct environments, the authors observed that mechanical damage and damage caused by moisture were responsible for the loss of vigor and viability of seeds in all environments.

\section{Conclusion}

In soybean seed production fields with high potassium content in the soil, the application of differing rates of potassium did not have immediate effects on seed quality.

\section{Acknowledgements}

The authors thank the CNPq (Conselho Nacional de Desenvolvimento Científico e Tecnológico), the Capes (Coordenação de aperfeiçoamento de pessoal de nível superior), and FAPEMIG (Fundação de Amparo à Pesquisa do Estado de Minas Gerais) for scholarships and the finnacial support, and the Federal University of Lavras for the logistic support.

\section{References}

[1] Pettigrew, W.T. (2008) Potassium Influences on Yield and Quality Production for Maize, Wheat, Soybean and Cotton. Physiologia Plantarum, 133, 670-681. http://dx.doi.org/10.1111/j.1399-3054.2008.01073.x 
[2] Veiga, A.D., Von Pinho, É.V.D.R., Veiga, A.D., Pereira, P.H.D.A.R., Oliveira, K.C.D. and Von Pinho, R.G. (2010) Influência do Potássio e da Calagem na Composição Química, Qualidade Fisiológica e Na Atividade Enzimática de Sementes de Soja. Ciência e Agrotecnologia, 34, 953-960. http://dx.doi.org/10.1590/S1413-70542010000400022

[3] Pedroso Neto, J.C. and Rezende, P.M. (2005) Doses e Modos de Aplicação de Potássio na Produtividade de Grãos e Qualidade de Semente de Soj a (Glycine max (L.), Merrill). FAZU em Revista, 27-36.

[4] Vyn, T.J.Y.X., Bruulsema T.W., Jackson, C.-J.C., Rajcan, I. and Brouder, S.M. (2002) Potassium Fertilization Effects on Isoflavone Concentrations in Soybean [Glycine max (L.) Merr.]. American Chemical Society, 50, 3501-3506. http://dx.doi.org/10.1021/jf0200671

[5] Sfredo, G.J. (2008) Soja No Brasil: Calagem, Adubação e Nutrição Mineral. Empresa Brasileira de Pesquisa Agropecuária, Embrapa Soja.

[6] Krueger, K.G.A., Mallarino, A.P. and Mullen, R.E. (2013) Phosphorus and Potassium Fertilization Effects on Soybean Seed Quality and Composition. Crop Science, 53, 602. http://dx.doi.org/10.2135/cropsci2012.06.0372

[7] BRASIL (2009) Ministério da Agricultura, Pecuária e Abastecimento. Regras para Análise de Sementes.

[8] Marcos Filho, J. (1999) Teste de Envelhecimento Acelerado. In: Krzyzanowski, F.C., Vieira, R.D. and França Neto, J.B., Eds., Vigor de Sementes: Conceitos e Testes, ABRATES, Londrina, 1-24.

[9] Maguire, J.D. (1962) Speed of Germination-Aid in Selection and Evaluation for Seedling Emergence and Vigor. Crop Science, 2, 176-177. http://dx.doi.org/10.2135/cropsci1962.0011183X000200020033x

[10] França-Neto, J.B., Krzyzanowski, F.C. and Costa, N.P. (1998) O Teste de Tetrazólio em Sementes de Soja.

[11] Krzyzanowski, F.C., Vieira, R.D. and Neto, J.B.F. (1999) Vigor de Sementes: Conceitos e Testes. Associação Brasileira de Tecnologia de Sementes, Comitê de Vigor de Sementes.

[12] Scott, A.J. and Knott, M.A. (1974) A Cluster Analysis Method for Grouping Means in the Analysis of Variance. Biometrics, 30, 507-512. http://dx.doi.org/10.2307/2529204

[13] Ferreira, D.F. (2011) Sisvar: A Computer Statistical Analysis System. Ciência e Agrotecnologia, 35, 1039-1042.

[14] Schnebly, S.R. and Fehr, W.R. (1993) Effect of Years and Planting Dates on Fatty Acid Composition of Soybean Genotypes. Crop Science, 33, 716-719. http://dx.doi.org/10.2135/cropsci1993.0011183x003300040016x

[15] Ávila, M.R., Braccini, A.L., Motta, I.S., Scapim, C.A. and Braccini, M.C. (2003) Sowing Seasons and Quality of Soybean Seeds. Scientia Agricola, 60, 245-252. http://dx.doi.org/10.1590/s0103-90162003000200007

[16] Lima, W.F., Pípolo, A.E., Moreira, J.U., de Carvalho, V.C.G.P., Prete, C.E.C. and Arias, C.A.A. (2008) Interação Genótipo-Ambiente de Soja Convencional e Transgênica Resistente a Glifosato, no Estado do Paraná. Pesquisa Agropecuária Brasileira, 43, 729-736. http://dx.doi.org/10.1590/s0100-204x2008000600009

[17] Gomes, G.D.R., Benin, G., Rosinha, R.C., Galvan, D., Pagliosa, E.S., Pinnow, C., et al. (2012) Produção e Qualidade Fisiológica de Sementes de Soja em Diferentes Ambientes de Cultivo. Semina: Ciências Agrárias, 33, 2593-2604. http://dx.doi.org/10.5433/1679-0359.2012v33supl1p2593

[18] de Pádua, G.P., Zito, R.K., Rantes, N.E. and Neto, J.D.B.F. (2010) Influência do Tamanho da Semente na Qualidade Fisiológica e na Produtividade da Cultura da Soja. Revista Brasileira de Sementes, 32, 9-16. http://dx.doi.org/10.1590/s0101-31222010000300001

[19] Mascarenhas, H.A.A., Bullsani, E.A., Miranoa, M.A.C., Braga, N.R. and Carlos, V.N.A.J. (1988) Deficiência de Potássio em Soja no Estado de São Paulo: Melhor Entendimento do Problema e Possíveis Soluções. Informações Agronômicas, 42, 1-4.

[20] Carraro, I.M. and Peske, S.T. (2005) Uso de Sementes de Soja no Estado do Paraná. Revista Brasileira de Sementes, 27, 75-80. http://dx.doi.org/10.1590/s0101-31222005000200011

[21] Lopes, K.P., Bruno, R.L.A., Costa, R.F., Bruno, G.B. and Rocha, M.S. (2006) Efeito do Beneficiamento na Qualidade Fisiológica e Sanitária de Sementes do Algodoeiro Herbáceo. Revista Brasileira de Engenharia Ambiental, 10, 426435. http://dx.doi.org/10.1590/s1415-43662006000200025

[22] Binotti, F.F.S., Haga, K.I., Cardoso, E.D., Alves, C.Z., de Sá, M.E. and Arf, O. (2008) Efeito do Período de Envelhecimento Acelerado no Teste de Condutividade Elétrica e na Qualidade Fisiológica de Sementes de Feijão. Acta Scientiarum Agronomy, 30, 247-254. http://dx.doi.org/10.4025/actasciagron.v30i2.1736

[23] Henning, A.A. and Neto, J.B.F. (1980) Problemas na Avaliação da Germinação de Semente de Soja Com Alta Incidência de Phomopsis sp. Revista Brasileira de Sementes, 2, 9-22.

[24] Bizzetto, A. and Homechin, M.R. (1997) Efeito do Período e da Temperatura de Armazenamento na Qualidade Fisiológica e Sanitária de Sementes de Soja com Altos íNdices de Phomopsissojae (Leh.). Revista Brasileira de Sementes, 19, 296-303.

[25] Dan, L.G.M., Dan, H.A., Barroso, A.L.L. and Braccini, A.D.L. (2010) Qualidade Fisiológica de Sementes de Soja 
Tratadas com Inseticidas sob Efeito do Armazenamento. Revista Brasileira de Sementes, 32, 131-139. http://dx.doi.org/10.1590/s0101-31222010000200016

[26] Neto, J.B.F., Krzyzanowski, F.C. and Henning, A.A. (2010) A Importância do Uso de Semente de Soja de Alta Qualidade. Informativo ABRATES, 20, 37-38.

[27] Torres, S.B. and Filho, J.M. (2001) Teste de Envelhecimento Acelerado em Sementes de Maxixe (Cucumisanguria L.). Revista Brasileira de Sementes, 23, 108-112.

[28] Guedes, R.S., Alves, E.U., de Oliveira, L.S.B., de Andrade, L.A., Gonçalves, E.P. and de Melo, P.A.R.F. (2011) Envelhecimento Acelerado na Avaliaçãoo da Qualidade Fisiologia de Sementes de Dalbergia nigra (Vell.) Fr. All. Semina: Ciências Agrárias, 32, 443-450. http://dx.doi.org/10.5433/1679-0359.2011v32n2p443

[29] AOSA (1983) Seed Vigor Testing Handbook. East Lansing.

[30] Vieira, R.D. and Krzyzanowski, F.C.T. (1999) Teste de Condutividade Elétrica. In: Krzyanowski, F.C., Vieira, R.D. and Neto, J.B.F., Eds., Vigor de Sementes: Conceitos e Testes, ABRATES, Londrina, 1-26.

[31] Trumper, E.V. and Edelstein, J.D. (2008) El Complejo de Chinchesfitofagosen Soja: Revision y Avances Enelestudio de su Ecologia y Manejo. [S.l.]: INTA.

[32] Sosa-Gomez, D.R. and Moscardi, F. (1995) Retencão Foliar Diferencial em Soja Provocada por Percevejos (Heteroptera: Pentatomidae). Anais da Sociedade Entomológica do Brasil, 24, 401-404.

[33] Belorte, L.C., Ramiro, Z.A., Faria, A.M. and Marino, C.A.B. (2003) Danos causados por percevejos (Hemiptera: Pentatomidae) em cinco cultivares de soja (Glycinemax (L.) Merrill, 1917) no município de Araçatuba, SP. Arquivos do Instituto Biológico,70, 169-175. 
Scientific Research Publishing (SCIRP) is one of the largest Open Access journal publishers. It is currently publishing more than 200 open access, online, peer-reviewed journals covering a wide range of academic disciplines. SCIRP serves the worldwide academic communities and contributes to the progress and application of science with its publication.

Other selected journals from SCIRP are listed as below. Submit your manuscript to us via either submit@scirp.org or Online Submission Portal.
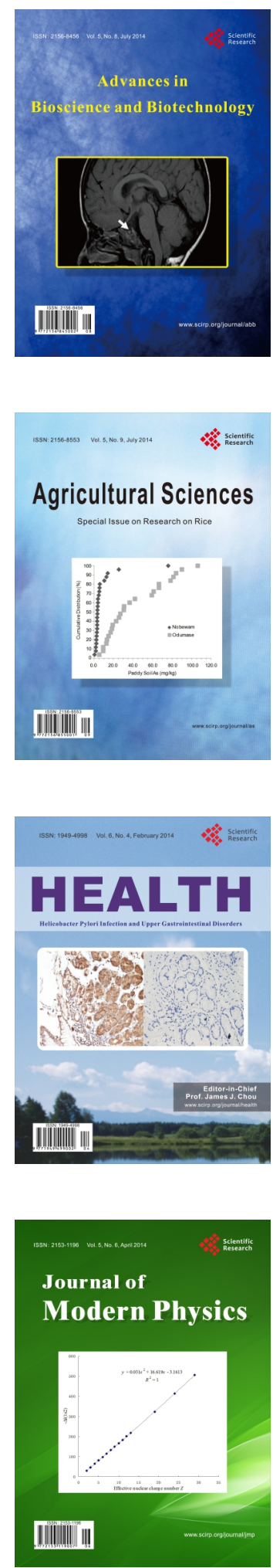
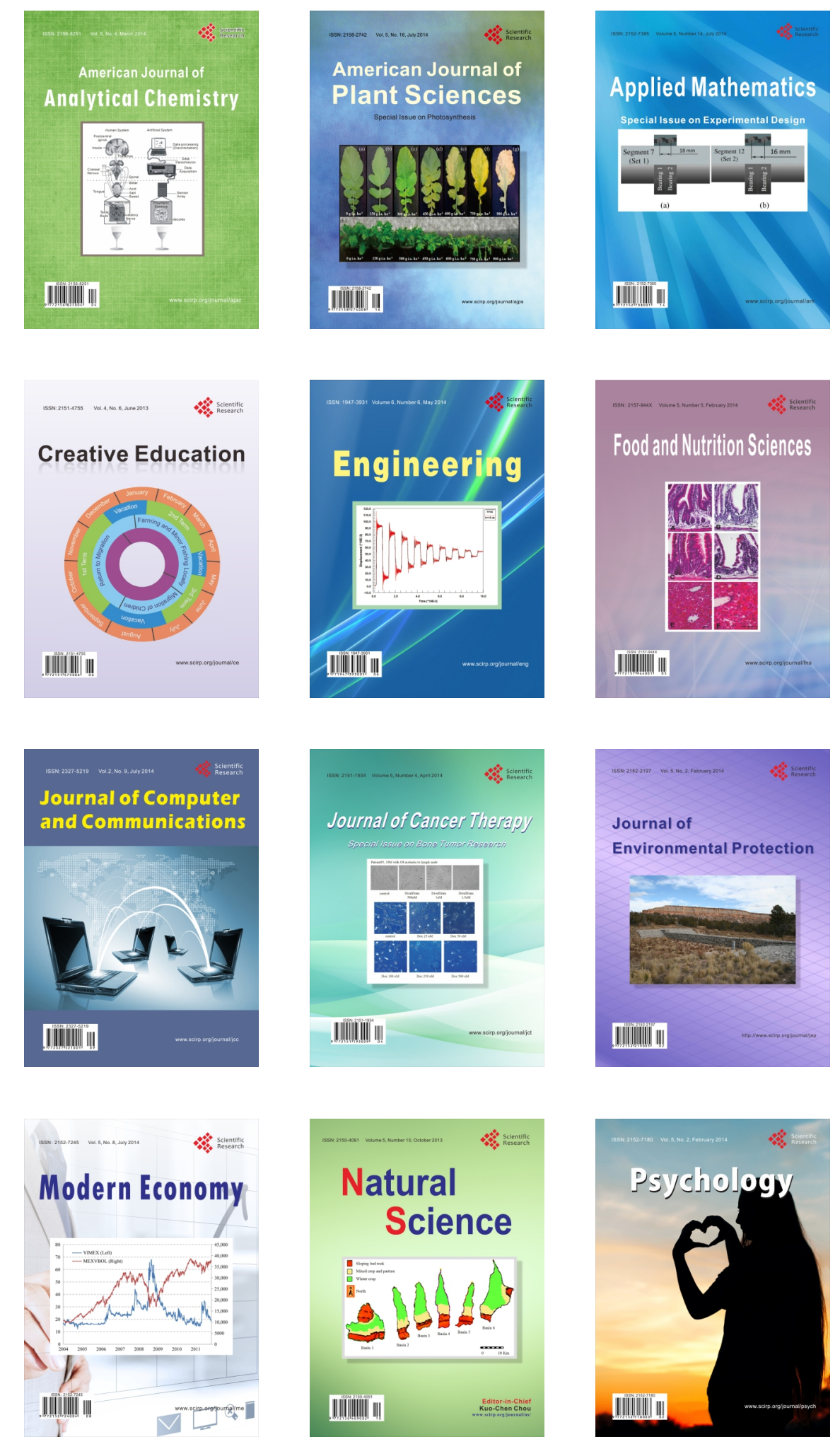